\title{
CORRIGENDUM
}

\section{Japanese men have larger areas of visceral adipose tissue than Caucasian men in the same levels of waist circumference in a population-based study}

T Kadowaki, A Sekikawa, K Murata, H Maegawa, T Takamiya, T Okamura, A El-Saed, N Miyamatsu, D Edmundowicz, Y Kita, K Sutton-Tyrrell, LH Kuller and H Ueshima

International Journal of Obesity (2012) 36, 1371; doi:10.1038/ijo.2012.148

$\begin{array}{cccc}\text { Correction to: International Journal of Obesity } & (2006) & 30 \text {, } \\ 1163-1165 ; & \text { doi:10.1038/sj.ijo.0803248; published online } 31\end{array}$ January 2006

Since the publication of this paper it has been noticed that there is an error in Table 1.

Table 1 on Page 1164.
Unit for VAT and SAT

Although we reported our unit in $\mathrm{cm}^{2}$, the correct unit is $\mathrm{cm}^{3}$ per $0.6-\mathrm{cm}$ height. Dividing the value by 0.6 gives the number in $\mathrm{cm}^{2}$.

These changes to do not affect the results or conclusions and the authors apologise for this error. 